\title{
АНАЛІЗ РЕСУРСІВ СИСТЕМИ НАДАННЯ ПЕРВИННОЇ МЕДИЧНОЇ ДОПОМОГИ НАСЕЛЕННЮ УКРАЇНИ ПРИ ХРОНІЧНОМУ ОБСТРУКТИВНОМУ ЗАХВОРЮВАННІ ЛЕГЕНЬ
}

\author{
Національна медична академія післядипломної освіти імені П. Л. Шупика, м. Київ, Україна
}

\begin{abstract}
Мета: вивчення ресурсів системи надання первинної медичної допомоги населенню України при хронічному обструктивному захворюванні легень.

Матеріали і методи. Наказом МОЗ України від 27.06.2013 р. № 555 передбачено відповідний обсяг надання медичної допомоги пацієнтам із хронічним обструктивним захворюванням легень лікарем загальної практики сімейним лікарем.

Результати. Провівши аналіз ресурсів системи надання первинної медичної допомоги при хронічному обструктивному захворюванні легень, встановлено, що наразі відсутній чіткий механізм діяльності закладів охорони здоров'я, які надають медичну допомогу пацієнтам із хронічним обструктивним захворюванням легень, немає фрактичного розмежування їх за рівнями, наявний кадровий десріцит лікарів, відзначається низький рівень матеріально-технічного та фрінансового забезпечення галузі.

Висновки. Впровадження нових організаційних засад щодо надання первинної медичної допомоги, які передбачатимуть вирішення питань діяльності закладів охорони здоров'я різних рівнів, кадрового десріциту лікарів, підвищення матеріально-технічного та фрінансового забезпечення первинної медико-санітарної допомоги, дасть змогу пацієнтам із хронічним обструктивним захворюванням легень отримувати якісну медичну допомогу, зберегти здоров'я та забезпечити перспективу подальшого життя на достатньому фрізичному та соціальному рівнях.
\end{abstract}

КЛЮЧОВІ СЛОВА: хронічне обструктивне захворювання легень; первинна медична допомога; ресурси закладів охорони здоров'я.

Одним із найтяжчих захворювань людини $€$ хронічне обструктивне захворювання легень (далі - ХОЗЛ), розповсюдженість якого постійно зростає [7]. В Україні ХОЗЛ є однією з основних причин інвалідизації та смертності громадян працездатного віку [3].

Ключову роль щодо профілактики та раннього виявлення ХОЗЛ у населення відіграють медичні працівники закладів первинної медичної допомоги [6]. Але для еорективної діяльності первинної ланки необхідне достатнє кадрове забезпечення галузі лікарями загальної практики - сімейними лікарями, підвищення фрінансування та матеріально-технічна модернізація первинної медикосанітарної допомоги.

У 2012 р. Національним інститутом стратегічних досліджень було опубліковано аналітичну записку «Щодо кадрової політики у рефрормуванні вітчизняної сорери охорони здоров'я» [2], яка засвідчила наявність в Україні значного кадрового деоіциту медичних працівників, особливо лікарів загальної практики - сімейних лікарів. Також було вказано на щорічне зростання міжгалузевої та трудової міграції.

У 2017 р. вийшла праця М. І. Линника та співавторів «Порівняльні дані про розповсюдженість хвороб органів дихання і медичну допомогу

(с) А. Г. Васильєв, 2018 хворим на хвороби пульмонологічного та алергологічного профрілю в Україні за 2010-2016 рр.» [8], в якій було викладено статистичні дані за 7-річний період щодо багатьох важливих показників діяльності пульмонологічної служби. Відповідно до отриманих статистичних даних було визначено значне скорочення кількості лікарів-пульмонологів та закладів, які мають пульмонологічні кабінети, разом із тим, спостерігають тенденцію до зростання показників розповсюдженості, захворюваності та смертності на основні інвалідизуючі хвороби органів дихання.

Мета роботи: вивчення ресурсів системи надання первинної медичної допомоги населенню України при хронічному обструктивному захворюванні легень.

Матеріали і методи. У 2007 р. 3 метою удосконалення надання медичної допомоги хворим із захворюваннями дихальної системи МО3 України було прийнято наказ від 19 березня 2007 р. № 128 «Про затвердження клінічних протоколів надання медичної допомоги за спеціальністю «Пульмонологія» [9], яким було затверджено окремий клінічний протокол надання медичної допомоги хворим на хронічне обструктивне захворювання легень. Але цей протокол не передбачав поділу надання медичної допомоги пацієнтам із ХОЗЛ за рівнями. 
Враховуючи принцип затвердженої трирівневої системи медичної допомоги було прийнято наказ МОЗ України від 27 червня 2013 р. № 555 «Про затвердження та впровадження медикотехнологічних документів зі стандартизації медичної допомоги при хронічному обструктивному захворюванні легень», яким затверджено Уніфікований клінічний протокол первинної, вторинної (спеціалізованої), третинної медичної допомоги та медичної реабілітації «Хронічне обструктивне захворювання легень» [10]. Положення Унісрікованого клінічного протоколу медичної допомоги спрямовані на мультидисциплінарне надання медичної допомоги пацієнтам із ХОЗЛ і охоплюють всі етапи надання медичної допомоги. Лікарі загальної практики - сімейні лікарі відіграють ключову роль у підвищенні обізнаності пацієнта, своєчасному виявленні та профілактиці ХОЗЛ.

Разом із тим, практика, що склалася в Україні, свідчить про фактичну відсутність розмежування закладів охорони здоров'я, в яких надають медичну допомогу різних рівнів, що негативно впливає на якість надання медичної допомоги. На первинному рівні повинно розпочинатися і завершуватися до 90 \% звернень за медичною допомогою. Та, відповідно до даних офріційного сайту МОЗ України [5], в нашій державі на первинному рівні розпочинають і завершують лікування лише до $30 \%$ пацієнтів у містах і до 50 \% - у сільській місцевості.

Великою проблемою на сьогодні в Україні $€$ кадровий дефріцит медичних працівників $[1,9]$. Так, за даними Д3 «Центр медичної статистики МО3 України», в Україні на початок 2017 р. відзначали наявний дефіцит 21,7 тис. лікарів та 22,1 тис. медичних сестер [3].

За даними Державної служби зайнятості (на 1 лютого 2018 р.), найбільш дефріцитними спеціальностями в медицині є сімейні лікарі (129 вільних вакансій), педіатри (78), терапевти (57) [4]. Крім того, за різними даними, з України на роботу за кордон щорічно виїжджають до 6-7 тис. медичних працівників [1, 2].

Та враховуючи, що згідно з новими змінами діяльності вітчизняної системи охорони здоров'я ключову роль у профрілактиці та діагностиці у громадян різних хронічних захворювань, у тому числі ХОЗЛ, мають відігравати лікарі первинної ланки, саме їх достатня укомплектованість $€$ пріоритетним питанням. Наразі кількість лікарів загальної практики - сімейних лікарів становить близько 13 тис. осіб, вакантними залишаються приблизно 6 тис. місць [5].

Не менш важливими є питання сучасного та достатнього матеріально-технічного та фрінансового забезпечення системи первинної медичної допомоги в Україні. В останні роки в Україні спостерігають збільшення кількості центрів первинної медико-санітарної допомоги. Але разом із відкриттям нових закладів охорони здоров'я збільшується і потреба в їх матеріально-ресурсному забезпеченні.

Як відомо, «золотим стандартом» діагностики й оцінки перебігу хронічного обструктивного захворювання легень $€$ спірометрія. Наказом МO3 України від 27 червня 2013 р. № 555 «Про затвердження та впровадження медико-технологічних документів зі стандартизації медичної допомоги при хронічному обструктивному захворюванні легень» передбачено наявність в закладах первинної медичної допомоги спірометра чи піколлуометра [10]. Відтак, обов'язковою умовою дослідження пацієнтів із підозрою на ХОЗЛ є виконання спірометричного обстеження за допомогою портативних спірометрів.

Результати дослідження та їх обговорення. Незважаючи на вищезазначені накази, далеко не всі медичні заклади мають у своїй наявності спірометр чи пікфлуометр. Головна причина - мізерний рівень фрінансування медичної галузі.

Окремо потрібно відзначити відсутність державної цільової програми чи хоча б часткової фрінансової підтримки з боку держави щодо забезпечення пацієнтів із хронічним обструктивним захворюванням легень медикаментозним лікуванням, що значно погіршує перспективи одужання таких пацієнтів та їх подальшу соціальну реабілітацію.

у сучасних умовах державотворення, коли на перше місце виходить охорона громадського здоров'я, пріоритетним завданням медичної галузі $€$ розвиток напрямку раннього виявлення та профрілактики захворювань, що мають високий ризик інвалідизації. Відтак на сьогодні головну роль у підвищенні обізнаності пацієнта, своєчасному виявленні та профрілактиці ХОЗЛ відіграють лікарі загальної практики - сімейні лікарі. Тому вкрай важливим є можливість застосування лікарями первинної ланки сучасних ефективних методів скринінгу населення на ХОЗЛ з урахуванням практично доступних їм технологій, що дасть змогу не лише вчасно надати пацієнтам із ХОЗЛ якісне та ефективне лікування, але й в цілому покращити стан громадського здоров'я України.

\section{Висновки}

На сьогодні затверджено основні галузеві нормативно-правові акти, які визначають пріоритети формування державної політики в системі охорони здоров'я України, але законодавчо не врегульовані питання, які регламентують розмежування лікувально-профрілактичних закладів за рівнями надання медичної допомоги. Тому потрібно розробити чіткий механізм діяльності закладів охорони здоров'я за рівнями, удосконалити маршрутизацію пацієнтів із ХОЗЛ та закріпити за кожним рівнем медичної допомоги відповідний перелік медичних послуг. 
Кадрова складова є однією з найважливіших у медичній галузі, але, на жаль, протягом останніх років в Україні спостерігають негативну тенденцію щодо чисельності як лікарів загальної практики сімейних лікарів, так і вузькопрофрільних лікарів, зокрема лікарів-пульмонологів. Лише ефективна державна кадрова політика може стати потужним інструментом забезпечення фрункціонування галузі охорони здоров'я. Це ж стосується і матеріально-технічного та фрінансового забезпечення системи охорони здоров'я.

Діючий Уніфікований клінічний протокол надання медичної допомоги пацієнтам із ХОЗЛ містить вичерпні рекомендації щодо профілактики та лікування захворювання, проте не містить інформації щодо ефективних методів скринінгу населення на ХОЗЛ з урахуванням практично доступних технологій, використання яких дозволить підвищити ефективність роботи лікаря за рахунок стандартизації надання медичної допомоги пацієнтам та оптимізації вартості лікування.
Підсумовуючи вищевикладене, можна стверджувати, що впровадження нових організаційних засад щодо надання первинної медичної допомоги, які передбачатимуть вирішення питань діяльності закладів охорони здоров'я різних рівнів, кадрового дефіциту лікарів, підвищення матеріально-технічного та фрінансового забезпечення первинної медико-санітарної допомоги, дасть змогу пацієнтам із ХОЗЛ отримувати якісну медичну допомогу, зберегти здоров'я та забезпечити перспективу подальшого життя на достатньому фрізичному та соціальному рівнях.

Перспективи подальших досліджень. Враховуючи, що сучасне розуміння державного управління в системі охорони здоров'я полягає у забезпеченні якісної та доступної медичної допомоги, що ґрунтується на засадах сімейної медицини, подальші наукові дослідження повинні бути спрямовані на вирішення питань удосконалення роботи первинної медико-санітарної допомоги.

\section{Список літератури}

1. Сучасна міграція українців до Польщі та пов'язані з нею виклики : аналітична записка [Електронний ресурс] / Національний інститут стратегічних досліджень. - Режим доступу : http://www.niss.gov.ua/articles/2934/.

2. Щодо кадрової політики у реформуванні вітчизняної соери охорони здоров'я : аналітична записка [Електронний ресурс] / Національний інститут стратегічних досліджень. - Режим доступу : http://www.niss.gov.ua/articles/808/.

3. Дані з офріційного сайту Державного закладу «Центр медичної статистики МОЗ України» [Електронний ресурс]. Режим доступу : http://medstat.gov.ua/ukr/main.html.

4. Дані з офріційного сайту Державної служби зайнятості [Електронний ресурс]. - Режим доступу : https://www.dcz. gov.ua/.

5. Дані з офіційного сайту Міністерства охорони здоров'я України [Електронний ресурс]. - Режим доступу : http:// moz.gov.ual.

6. Ільченко С. І. Роль спірометричного моніторингу та визначення рівня неспецифрічної бронхіальної чутливості в первинній профрілактиці ХОЗЛ серед підлітків / С. І. Ільченко // Український пульмонологічний журнал. - 2014. № 3. - С. 68-70.

7. Кулінич-Міськів М. О. Сучасні аспекти діагностики і лікування хронічного обструктивного захворювання легень у світлі нових міжнародних рекомендацій GOLD / М. О. Кулінич-Міськів, М. М. Островський, О. І. Варунків // Туберкульоз, легеневі хвороби, ВІЛ-інфекція. - 2014. - № 1. - С. 90-96.

8. Порівняльні дані про розповсюдженість хвороб органів дихання і медичну допомогу хворим на хвороби пульмонологічного та алергологічного профілю в Україні за 2010-2016 рр. / М. І. Линник, О. П. Недоспасова, О. Р. Тарасенко [та ін.]. - К. : Видавництво Ліра, 2017. - 48 с.

9. Про затвердження клінічних протоколів надання меддопомоги за спеціальністю «Пульмонологія»: наказ Міністерства охорони здоров'я України від 19.03.2007 р. № 128 [Електронний ресурс]. - Режим доступу : httр:// search.ligazakon.ua/l_doc2.nsf/link1/MOZ6749.html.

10. Про затвердження та впровадження медико-технологічних документів зі стандартизації медичної допомоги при хронічному обструктивному захворюванні легень : наказ Міністерства охорони здоров'я України від 27 червня 2013 р. № 555 [Електронний ресурс]. - Режим доступу : http://search.ligazakon.ua/l_doc2.nsf/link1/MOZ20082.html.

\section{References}

1. Analitychna zapyska. Suchasna mihratsiia ukraintsiv do Polshchi ta poviazani z neiu vyklyky [Analytical note. Modern migration of Ukrainians to Poland and challenges associated with it]. Retrieved from: http://www.niss.gov.ua/articles/2934/ [in Ukrainian].

2. Analitychna zapyska. Shchodo kadrovoi polityky u reformuvanni vitchyznianoi sfery okhorony zdorovia [Analytical note. Regarding the personnel policy in the reform of the domestic healthcare sector]. Retrieved from: http://www.niss.gov.ua/ articles/808/ [in Ukrainian].

3. Dani z ofitsiinoho saitu Derzhavnoho zakladu "Tsentr medychnoi statystyky MOZ Ukrainy" [Data from the official website of the State institution "Center for Medical Statistics of the Ministry of Health of Ukraine"]. Retrieved from: http://medstat. gov.ua/ukr/main.html. [in Ukrainian].

4. Dani z ofitsiinoho saitu Derzhavnoi sluzhby zainiatosti [Data from the official website of the State Employment Service]. Retrieved from: https://www.dcz.gov.ua/ [in Ukrainian]. 
5. Dani z ofitsiinoho saitu Ministerstva okhorony zdorovia Ukrainy [Data from the official site of the Ministry of Health of Ukraine]. Retrieved from: http://moz.gov.ua/ [in Ukrainian].

6. Ilchenko, S.I. (2014). Rol spirometrychnoho monitorynhu ta vyznachennia rivnia nespetsyfichnoi bronkhialnoi chutlyvosti $\checkmark$ pervynnii profilaktytsi KhOZL sered pidlitkiv [The role of spirometric monitoring and determination of nonspecific bronchial sensitivity in primary prevention of COPD among adolescents]. Ukrainskyi pulmonolohichnyi zhurnal - Ukrainian Pulmonology Journal, 3, 68-70 [in Ukrainian].

7. Kulinych-Miskiv, M.O., Ostrovskyi, M.M., \& Varunkiv, O.I. (2014). Suchasni aspekty diahnostyky i likuvannia khronichnoho obstruktyvnoho zakhvoriuvannia lehen u svitli novykh mizhnarodnykh rekomendatsii GOLD [Modern aspects of diagnosis and treatment of chronic obstructive pulmonary disease in light of new international recommendations GOLD]. Tuberkuloz, lehenevi khvoroby, VIL-infektsiia - Tuberculosis, Pulmonary Diseases, HIV Infection, 1, 90-96 [in Ukrainian].

8. Lynnyk, M.I., Nedospasova, O.P., Tarasenko, O.R., Kapustiak, V.I., Bushura, I.V., \& Nikiforova, L.H. (2017). Porivnialni dani pro rozpovsiudzhenist khvorob orhaniv dykhannia i medychnu dopomohu khvorym na khvoroby pulmonolohichnoho ta alerholohichnoho profiliu v Ukraini za 2010-2016 rr. [Comparative data on the prevalence of respiratory diseases and medical care for patients with pulmonologic and allergic diseases in Ukraine for 2010-2016]. Kyiv: Vydavnytstvo Lira [in Ukrainian].

9. Nakaz Ministerstva okhorony zdorovia Ukrainy vid 19 bereznia 2007 roku № 128 "Pro zatverdzhennia klinichnykh protokoliv nadannia medychnoi dopomohy za spetsialnistiu "Pulmonolohiia" [Order of the Ministry of Health of Ukraine of March 19, 2007, No. 128 "On Approval of Clinical Protocols for the Provision of Medical Aid in the Specialty "Pulmonology"]. Retrieved from: http://search.ligazakon.ua/l_doc2.nsf/link1/MOZ6749.html [in Ukrainian].

10. Nakaz Ministerstva okhorony zdorovia Ukrainy vid 27 chervnia 2013 roku № 555 "Pro zatverdzhennia ta vprovadzhennia medyko-tekhnolohichnykh dokumentiv zi standartyzatsii medychnoi dopomohy pry khronichnomu obstruktyvnomu zakhvoriuvanni lehen" [Order of the Ministry of Health of Ukraine dated June 27, 2013 № 555 "On Approval and Implementation of Medical-Technological Documents for Standardization of Medical Assistance in COPD"]. Retrieved from: http://search.ligazakon.ua/l_doc2.nsf/link1/MOZ20082.html [in Ukrainian].

\section{АНАЛИЗ РЕСУРСОВ СИСТЕМЫ ПРЕДОСТАВЛЕНИЯ ПЕРВИЧНОЙ МЕДИЦИНСКОЙ ПОМОЩИ НАСЕЛЕНИЮ УКРАИНЫ ПРИ ХРОНИЧЕСКОЙ ОБСТРУКТИВНОЙ БОЛЕЗНИ ЛЕГКИХ}

А. Г. Васильев

Национальная медицинская академия последипломного образования имени П. Л. Шупика, г. Киев, Украина

Цель: изучение ресурсов системы оказания первичной медицинской помощи населению Украины при хронической обструктивной болезни легких.

Материалы и методы. Приказом МЗ Украины от 27.06.2013 г. № 555 предусмотрено определенный объем оказания медицинской помощи пациентам с хронической обструктивной болезнью легких врачом общей практики - семейным врачом.

Результаты. Проведя анализ ресурсов системы оказания первичной медицинской помощи при хронической обструктивной болезни легких, установлено, что в настоящее время отсутствует четкий механизм деятельности учреждений здравоохранения, оказывающих медицинскую помощь пациентам с хронической обструктивной болезнью легких, нет фрактического разграничения их по уровням, есть кадровый дефицит врачей, отмечается низкий уровень материально-технического и фринансового обеспечения отрасли.

Выводы. Внедрение новых организационных основ по предоставлению первичной медицинской помощи, предусматривающие решение вопросов деятельности учреждений здравоохранения различных уровней, кадрового дефицита врачей, повышение материально-технического и финансового обеспечения первичной медико-санитарной помощи, позволит пациентам с хронической обструктивной болезнью легких получать качественную медицинскую помощь, сохранить здоровье и обеспечить перспективу дальнейшей жизни на достаточном физическом и социальном уровнях.

КЛЮЧЕВЫЕ СЛОВА: хроническая обструктивная болезнь легких; первичная медицинская помощь; ресурсы учреждений здравоохранения.

\section{ANALYSIS OF THE SYSTEM RESOURCES OF PROVIDING PRIMARY MEDICAL AID TO THE UKRAINIAN PEOPLE WITH CHRONIC OBSTRUCTIVE PULMONARY DISEASE}

A. H. Vasylyev

P. Shupyk National Medical Academy of Postgraduate Education, Kyiv, Ukraine

Purpose: to study of the system resources of rendering of primary medical aid to the population of Ukraine at COPD.

Materials and Methods. Order of the Ministry of Health of Ukraine dated June 27, 2013 No. 555 provides for the provision of medical care for patients with COPD by a general practitioner - a family doctor.

Results and Discussion. Having analyzed the resources of the primary care system for COPD, it was established that there is currently no clear mechanism for the activities of health care institutions providing 
medical care to patients with COPD, there is no actual demarcation of them according to the levels, there is a personnel shortage of doctors, there is a low level of material and technical and financial security industry.

Conclusions. The introduction of new organizational principles for provision of primary health care that will address the issues of activity of health facilities of different levels, staff shortages of doctors, increase of material and technical and financial support of primary health care will allow patients with COPD to receive qualitative medical care, preserve health and ensure the prospect of further life on a sufficiently physical and social level.

KEY WORDS: chronic obstructive pulmonary disease; primary health care; resources of health facilities.

Рукопис надійшов до редакції 23.07.2018 p.

\section{Відомості про автора:}

Васильєв Авер'ян Григорович - аспірант кафедри управління охороною здоров'я Національної медичної академії післядипломної освіти імені П. Л. Шупика; тел. +38(050) 311-85-04. 